\title{
Evolution of the knowledge economy: a historical perspective with an application to the case of Europe
}

\section{"The empires of the future are the empires of the mind."}

Sir Winston Churchill

Speech at Harvard, 6 September 1943, in Onwards to Victory (1944)

\begin{abstract}
The goal of the article is to explore the evolution of original concept of knowledge economy based on science intensive production sectors toward service type economies which significantly changed the role of scientific research and technological innovation for economic growth. The paper argues that this transition is due not only to the structural changes in global production, but the theoretical evolution and paradigmatic shift of the concept of "knowledge economy" in general and "knowledge" in particular has played a significant role. The paper examines the different interpretation of knowledge within new types of intangible economies (e.g., new/Internet, weightless, service, creative, cultural economies) where knowledge is perceived to be generated not as a product of scientific research but as a service or creative activity and critically examined the role of scientific research in a service led knowledge economy. Additionally the paper argue how these phenomena, which marked the global economy in the last decades, enable the transition of the standard concept of knowledge economy originated from industrial production and manufacturing to a knowledge economy equalized with various types of expanding intangible economies, primarily those based on service and creative industries.
\end{abstract}

Key words: Knowledge economy; Concept evolution; European countries; Service economy; 


\section{Introduction}

The concept of the knowledge economy is embedded in a extensive tradition of economic and social theories. The knowledge economy concept is rooted in theories ranging from information theory (Machlup, 1962) to the theories of post-industrialism (Bell, 1973), as well as in the ideas of Drucker who coined the terms "knowledge society" (Drucker, 1969). Despite the existence of a vast body of literature on the knowledge economy, a coherent definition of this concept does not appear to have emerged (Carlaw et al, 2006). The most common definition is the one established by the OECD (1996), which describes the "knowledge economy" very broadly as an economy that is directly based on the production, distribution and use of knowledge and information.

Knowledge generated by scientific research in natural and technical sciences needs technological innovation and industry for its market exploitation. However, industrial production and technological innovation are in sharp decline, markets are saturated with industrial goods of all kinds while service activities continue to grow employing the rising share of workforce. Despite certain recovery of economic activities among the most developed members of the EU in 2013 (European Commission, 2013) and optimistic prognoses for 2015, there remains a common impression that the crisis has shaken trust in the ability of Europe's political and economic systems to deliver balanced economic growth (European Commission, 2012).

Differences in the levels of economic development within the EU persist despite the efforts made to support the convergence of less developed regions. These differences occur both when comparing countries and comparing regions in a country. Comparing the Gross Domestic Product (GDP) per capita in purchasing power standards (PPS), differences arise. For the 28 countries of the EU this average is equal to 100: although in 2013 GDP per capita 
in PPS for such countries like (e.g. Netherlands (131), Austria (128), and Sweden (127), significantly above the European average; for others, like for (e.g. Bulgaria (45), Romania (55), Croatia (61) and Latvia (64)) are well below. ${ }^{1}$

There are many reasons for such differences; historic, economic, and cultural. But the question is not only about the causes of this economic diversification but about the mechanisms of the most effective convergence tools as well. Technology change and innovation based on knowledge and scientific research are claimed to be the most important causes of diversification and at the same time one of the best ways for further development.

The changes of these original assumptions began with the disappointing results of Lisbon I (Kok, 2004) and moderate success of Lisbon II (European Commission 2010a; Johansson et al, 2007). The failure of the latter was attributed to the financial and economic crisis that hit Europe in 2008. However, it provided a boost for a new European agenda: the Europe 2020 Strategy and the Innovation Union as a flagship initiatives which is designed to deliver smart, sustainable and inclusive growth relay on a belief in the importance of innovation in development strategy. It is stated that: "Europe's future economic growth and jobs will increasingly have to come from innovation in products, services and business models. This is why innovation has been placed at the heart of the Europe 2020 strategy for growth and jobs!' It is recognized as a new beginning, a platform for new growth initiatives that will allow Europe to take advantage of this moment of transformation to recover from the global crisis in 2010 .

Conceptual and methodological approaches has been used to dealing with future of service economies are fairly diversified and includes both severe critics of its sustainably (Jansson, 2009; Oakley, 2004; Ketokivi, 2009, Wölfl, 2005; Solberg Søilen, 2012; Miles,

\footnotetext{
${ }^{1}$ based on Eurostat http://ec.europa.eu/eurostat/tgm/table.do?tab=table\&init=1\&language=en\&pcode=tec00114\&plugin=1
} 
2005; Witt, 2013) as well as its acceptance as an inevitable future that may pass different scenarios (Gallouj at all, 2015) physiological adjustments in (slow) growth (Antonelli and Fassio, 2014) or can take different forms such as "creativity" economy which interrelates creativity, knowledge and innovating economies (Dubina, at all, 2012).

The main research questions are: how has the original concept of knowledge based economy rooted in science intensive industries been equalized with the service economy where knowledge is understood not as activity of scientific research activity but as service or creative activity? How has the technological innovation in this process been exchanged for creativity and service activities as the driver of economy growth? And, is it possible transition of standard service economy often related to low-skills/wage jobs into "knowledge intensive service economy" (KISE) with higher proportion of high tech production and high-tech service sectors which could reconcile scientific research, technological innovation and service activities.

This paper is a conceptual paper with a methodology relies on critical qualitative research approach which involve in-depth understanding and description of the nature of a phenomenon under consideration. The statistical data are used where available and appropriate to illustrate the presented challenges of current knowledge based economy dominated by services.

For the purpose of exploring the established research questions, we examined in the second part of the paper the historical roots of knowledge economy with a view to consider the current stance knowledge economy in Europe. The third part discusses the evolution of the concept of knowledge economy that lead to the re-conceptualization of the knowledge economy which is discussed in the fourth part of the paper. The fifth part describes the changes in understanding the notion of "knowledge" within different types of emerging intangible economies which ended up in the concept of service economy as their common 
denominator. The six part explores the challenges of service economy supported by available analyses and statistical data that can serve as a motivation for fostering service economy more oriented to knowledge intensive activities and high/medium technologies. Lastly, the main thesis are recapitulated to suggest reconsideration of the concept of knowledge economy which suits the growth path of service economy.

\section{Is the Knowledge-based Economy in Europe under Threat?}

In the key European strategic documents produced over the last decade, transitioning to a knowledge economy has been a primary goal of the EU members. The need for this transition first arose in the mid-1990s, when the balance of global economic power was disturbed and Europe started to face growing unemployment, slow economic growth and lower competitiveness in the world market. In light of the widening economic gap between Europe and its main competitors (i.e., the US and Japan) and swiftly growing economies in places such as South Korea and China (European Commission (2011), the European Council set out the Lisbon Strategy (Lisbon I) in March 2000 (European Council, 2000), which offered an economic reform agenda directed toward transforming the European Union into a highly competitive and knowledge-based economy by 2010. The knowledge economy has remained a leitmotif of all subsequent strategies, including a re-launched Lisbon strategy (Lisbon II) (European Commission, 2005) and the Europe 2020 strategy issued in 2010 (European Commission, 2010).

The transition to the knowledge economy is driven by a growing recognition that longterm economic growth, employment, and social welfare are increasingly dependent upon a nation's capacity to generate, appropriate, and use new knowledge (Archibugi \& Coco, 2005). The technical advances produced by companies and scientific research and transformed into commercially viable innovations are perceived as driving the technological changes that 
produce accumulated technological progress at the aggregate level, which in turn generates economic growth and social prosperity for the nation. This transition also depends on the knowledge triangle of research, education and innovation described within the evolutionary theory of technological change (Nelson and Winter, 1982) and "systems of innovation" (Lundvall, 1992; Freeman, 1988) wherein interactions between knowledge, learning and business leaders facilitate conditions conducive to innovation.

In light of these dynamics, European strategic agendas were primarily concerned with setting up the policies and institutions necessary to accelerate the transformation of scientific research into commercially viable innovations and enhance the quality of the human capital available for knowledge creation and application. Since its inception, the Lisbon agenda has emphasized that its goals would necessitate enhancements in research infrastructure, including research investments in the private business sector and a fundamental transformation of education and training efforts throughout Europe.

Historically, the application of science in industry began in approximately 1850, during the second industrial revolution. During that time, industrial production began to change dramatically because technology was no longer mostly empirical and became grounded in science. The systematic application of scientific research and methods in industrial production (primarily in the areas of physics and chemistry) created the chemical and electrical industries, the first "industries of knowledge" (Rosenberg, 1985; Mokyr, 2003). Since then, industry has undergone a process of "scientification", drawing heavily upon the existing pool of knowledge and infrastructures provided by science (Dasgupta and David, 1988; Rosenberg and Nelson, 1994). The process behind industry's scientification is usually illustrated using a "transistor model" that demonstrates the dependence of new technological paradigms on scientific breakthroughs and knowledge resulting from organized and institutionalized research within industry (Nelson, 1959). Such knowledge is based on the codification of 
scientific and engineering research results and the formal (i.e., university) education required for understanding them and their application.

Preposition 1. Knowledge economy was steered by research-driven companies that followed the science to make innovations and gain productivity from $R \& D$.

Nowadays, the knowledge economy is related to the third industrial revolution, the information and biotechnology revolution that began in the US in the 1950s. In contrast with the first knowledge industries, where establishing the engineering disciplines at universities and the first industrial institutes within large corporations played a crucial role, in modern knowledge industries (i.e., the computer and biotechnological industries), the direct capitalization of scientific research through small academic spin-off companies has been key. Academic entrepreneurship began with ICT companies (primarily Hewlett-Packard (HP) and precursors such as Digital Equipment Corporations (DEC)), which then paved the way for Silicon Valley, the entire U.S. computer industry and the information age. A similar process marked the beginning of the biotechnological industry, whose foundations go back to another university spinoff company, Genentech, which was founded to allow for commercial exploitation of recombinant DNA, which was discovered in 1973 by scientists at the University of California and Stanford University (Hughes, 2011). The spectacular stock market success of biotech firms in the early 1980s demonstrated the economic value of university research and dramatically changed its role in economic development forever.

Subsequently, learned skills become distinctive resources as they are the product of their accretion and exploitation.

Preposition 2. Entrepreneurship arises when revolutionizing or reforming the pattern of production, exploiting an innovation or an untried technology for producing a new commodity, producing an old product in a new way, or a new outlet for products, or reorganizing the industry emerge. 
In the Theory of Economic Development (1934), Joseph Schumpeter describes destructive creation wherein an entrepreneur as an innovator disturbs economic equilibrium by creating new opportunities for socioeconomic development during times of uncertainty, change and technological upheaval. Hereafter, a firm must engage in product, process and organisational innovation to capitalize on perceived opportunities (Schumpeter, 1934). According to Kirzner (1973) innovation does not require macro-economic changes related to new technology or social trends, but entrepreneur is an arbitrageur who obtains profits from information asymmetries in incumbent markets that can be captured if discovered before others. Innovation is at the core of entrepreneurial activity and it integrate entrepreneurship, and institutional and network theories thereby explaining how partnerships enrich localised knowledge, social embeddedness within compound informal networks and ambidexterity in dealing with various stakeholder groups (Hitt, Ireland, and Lee, 2000).

Innovation is understood as an interactive process which refers to the behaviour of an enterprise in planning and implementing changes to their activities (Nauwelaers, Wintjes, 2002). Culture values within organisation (Turro, Urbano and Peris-Ortiz, 2014) or knowledge sharing relationships typically need to be stronger the more complex the innovation. Research activity itself has undergone two organizational phases:1) the institutionalization of $R \& D$ within formal $R \& D$ departments at large firms, and 2) the expropriation of research results by small high-technology companies (usually university spin-offs), which is common today. Growth in the number of small- and medium-sized technology companies emphasizes the fundamental role entrepreneurial capital plays (Audretsch, 2009) in sustaining the current knowledge economy. The role of entrepreneurs in transforming theoretical cognition and research results into productive knowledge (Block, Thurik and Zhou, 2013 distinguishes the current version of the knowledge economy from its 
original form. Today, to persist in the global economy, the knowledge economy requires a synergy between knowledge capital and entrepreneurship capital.

\section{The conceptual roots of the concept of the knowledge economy}

Changes in material production that promote a knowledge-based economy have occurred alongside the creation of a rich body of economic theories after the Second World War that tend to integrate science, technology and the economy. They include economic growth theories (Solow, 1957; Romer, 1989), catch-up theories (Abramowitz, 1989), theories of technological capabilities (Lall, 1995) and technological accumulation (Bell and Pavitt, 1993) among others. At the simplest level, these theories perceive scientific research that has been transformed into commercially viable innovations and technological advances as the principal drivers of technological change, which in turn produce the accumulated technological progress that generates economic growth.

Prepositions 3. Neoclassical growth theories itself have not offered any practical solutions for capitalizing on knowledge or turning knowledge into innovation so need for more policy oriented approach arise.

A breakthrough occurred with the discovery of technical change within Solow's Nobel prizewinning exogenous growth model (Solow, 1957), which perceived non-material production factors such as R\&D and education as primarily responsible for economic growth. Unlike the Solow model, which treats technology like "manna from heaven" that pours into human work and makes it more productive (Petit, 1995), new growth theories (Romer, 1989) suggest that deliberate investment in endogenous factors such as human capital and scientific research capture new knowledge and translate it into goods that enable unbounded economic growth. Both of these concepts influenced governments during the 1960s and 1990s, encouraging them to invest in scientific research as the "prime mover" of new technologies. It honestly 
believes by some that the Evolutionary theory may be an appropriate frame-of-reference to examine knowledge based economy to the European goals stream in the $21^{\text {st }}$ century. Inspired by the economic recession at the end of the 1970s, the evolutionary theory of technological change defined some best practices that policymakers could use to foster innovation (Nelson and Winter, 1982, Dosi and Nelson 1994). They emphasise radical technological innovations made during that time, and particularly the microelectronic revolution, as critical in solving that economic crisis. The coevolution of technologies, firms and industry structures and their supporting governing institutions were perceived as critical for generating innovation (Nelson, 2007). In contrast with neoclassical growth theories, which are based on a linear innovation process that begins with scientific research and ends with its successful commercialisation, evolutionary economists see innovation as an interactive process that paves the way for a non-linear interactive model of innovation, which Kline and Rosenberg (1986) described as a chain-linked model that had far-reaching consequences for scientific research's role in the innovation process. The chain-linked model usually begins with the identification of an unfilled market need and involves complex feedback loops between all the stages of innovation and their corresponding stakeholders. New knowledge or scientific research does not necessarily drive innovation. Instead, the minor modifications, improvements and other sorts of incremental innovation produced primarily by engineers (as opposed to scientists) are perceived as equally if not more important than research on economic growth. Although innovation still relies heavily upon technological knowledge, the chain-linked model marks, in practice, a break with the concept of science-based innovation. 


\section{Towards a Re-conceptualization of the Knowledge Economy}

In the final decades of 20th Century, when global competition steadily increased the demand for sophisticated science-based innovations, the knowledge economy became increasingly identified with industries rooted in research-intensive and high-technology sectors. Within these sectors, there were institutionalized research activities taking place in the formal R\&D departments of large firms that necessitated strong research investments in the public and private sectors. In the early 2000s, this science-centric conceptualization of the knowledge economy began to change drastically, as it was found to be too narrow developmental model for many countries exposed to globalization and "servitization" of economy. Moreover, the "scientification" of industry and high-tech sectors were increasingly being viewed negatively and became associated with the outdated and discredited linear model of innovation.

Preposition 4. A narrow understanding of the knowledge economy focused solely on high-tech sectors has produced at least three types of limitations that conceptually and practically constrain opportunities for economic growth in European economies; thus, this model required re-conceptualization.

The first limitation relates to the narrow scope of the innovation which encompasses research-based innovation but fail to cover a broad range of technological improvements and incremental innovations. The second limitation stems from almost exclusively prizing hightech sectors and the "glamorous" new technologies, which are difficult to produce even among technology leaders and which, in practice, comprise only a small part of economy. The third limitation pertains to the geographical concentration of research and technological capabilities within a small number of countries. In the case of Europe, only three Scandinavian countries invest more than $3 \%$ of their GDP in R\&D and can be considered research-driven economies. These limitations are compounded by the difficulties in material production produced by globalization and de-industrialization (which occurred with the 
collapse of traditional industries), relocation of industry to low-wage countries and the saturation of markets with goods of all sorts. The global financial crisis coupled with steep unemployment in manufacturing professions and the rise of service sectors have also highlighted the limitations of this narrow understanding of the knowledge economy.

It is quite clear that there are just a few high-technology sectors (Mendoca, 2009), and the cumulative impact of incremental innovations and subsequent improvements in more "radical-innovations" can have an economic impact (Kline and Rosenberg, 1986). However, traditional industries have faced downsizing, too, due to the decreased need for manufacturing and human labor, Asian imports and related phenomena such as the saturation of markets with branded consumer goods.

Routines are a key concept in the evolutionary theory. Nelson and Winter (1982, p. 399) define them as a "set of ways of doing things and ways of determining what to do" by wounding across the concepts of capabilities (techniques that firms use) and choices (behaviours that can be optimized). Within this narrow conceptualisation of the knowledge economy, many countries are excluded from the global technology race and expelled from the club of developed modern knowledge economies. Therefore, it was necessary to re-formulate, expand and soften the original concept of the knowledge economy (Carayannis et al, 2014). The service and creative economies have been increasingly favoured as potential platforms for future economic growth and employment (OECD, 2000), but it is not clear to what extent this trend is based on these economies' actual impact on economic growth, as opposed to uncertainty regarding how the national economy will sustain and progress.

Standard theories of technical change and technological progress based on industrial and technological innovation have been challenged by various types of soft innovations (e.g., organizational, social, or market) that increasingly blur the boundaries between the production 
and service sectors. There is a common perception that innovation is in crisis while the "future trends in innovation in most developed countries are uncertain" (OECD, 2012).

However, abandoning the "unrealistic" notion that science-based innovation could drive growth in the majority of countries has produced an unexpected result: the intangibles of scientific research that previously drove technological progress have been replaced by the intangibles of services and consumer innovations. Freeman and Soete (2007:12) concluded, for example, that technological progress has been more recently associated with knowledge service activities such as continuous attempts at ICT-based efficiency improvements in areas such as the financial and insurance sectors, the wholesale and retail sectors, health, education, government services, business management and administration.

The substitution of "service intangibles" for "knowledge intangibles" revises the original notion of innovation and enables the replacement of the knowledge economy with the service economy. The evolution of the concept of innovation and the knowledge economy are most visible, although still not dominant, within the frameworks of the creative and culture economies, which identify knowledge with creativity. The jump from scientific creativity to creativity in various other creative sectors is visible in the domains of entertainment, personal consumption and dematerialized consumer innovations such as Facebook, Twitter or Instagram.

This re-conceptualization started within mainstream economics, which abolished the classic definition of innovation as "the first application of science and technology in a new way, with commercial successes" (OECD, 1971:11) in favor of much broader one based on the Kline Rosenberg chain-linked model of innovation, which takes into account the nontechnological aspects of innovation (Adam, 2014:9). From a practical point of view, the Frascati manual (OECD, 2002), which measured research inputs into innovation, was complemented by the Oslo Manual (OECD, 2005:46), which focused on innovation outputs 
(Godin, 2011) and, in its latest edition, has broadened the definition of innovation to include organizational and marketing to ensure that policymakers take non-technological aspects of innovation into account (Godin, 2008).

This is not to deny the need for a broader definition of innovation that encompasses various types of non-research-based and incremental innovations (which are achieved primarily by growing sector of small firms), but rather, to demonstrate how deemphasizing technology innovation paved the way for re-conceptualizing the intangibles that represent the substance of the knowledge economy. This revised definition of innovation has been applied in composing the Community Innovation Survey, the European Commission's official instrument for measuring the innovation performance of its member states. The latest survey (CIS 6) reveals that marketing or organizational innovation prevailed over product or process innovation (Uppenberg and Strauss, 2010).

Furthermore, the chief models that the European Commission uses for reporting on state-ofthe-art of innovation performance among EU members - the Innovation Union Scoreboard (IUS) and its predecessor, the European Innovation Scoreboard (EIS)—are both focused on a rather colorful and arbitrary compilation of indictors that have been roundly criticized (Adam, 2014). These models assume that all indicators have an equal effect on national innovation performance, regardless of their technological embeddedness or research intensity. They reflect a general departure from the original concept of knowledge economy towards a changed conception that relativizes the importance of $R \& D$ and technological innovation in economic growth.

\section{What is knowledge in the knowledge economy?}

The most challenging question is how service innovation (and not technological innovation) came to be uncritically accepted as the primary driver of economic growth. This 
historical turnaround has resulted in the privileging of different types of current intangible economies that more or less ignore scientific research and technology as factors in growth and employment. These economies change the original notion of the knowledge economy, enabling it to evolve into more intangible or light economy. Several examples of these intangible economies can be identified (Author, 2012): the new ICT-based economy (OECD, 2000a), the weightless economy (Coyle, 1997; Quah, 1999), the creative economy (Howkins, 2001), the cultural economy (Hesmondhalgh, 2013), the financialized economy (Krippner, 2005:174) and the service economy (Maglio, Kieliszewski and Spohrer, 2010).

Today, the service economy tends to be viewed as a replacement for the knowledge economy, which creates many socio-economic changes whose full consequences remain unknown. However, a problem arises when trying to define what the "knowledge" referred to in these different types of intangible knowledge economies actually is. A short overview of the main drivers for each one can help define their specific knowledge bases and illustrate the substantial difference between the original knowledge economy and its successors.

Preposition 5. The service-type economies provide a new epoch of the knowledge economy but it cannot be equated with it.

The economies listed previously are notable for their post-industrial character and lack of emphasis on material (i.e., primarily industrial) production in favor of other intangible factors. In such economies, company assets do not consist of "land, labor and machinery" but rather the creativity, knowledge, skills, learning, information, intellectual property rights, good will, ideas and other similar soft factors that, in fact, underpin the original concept of the knowledge economy as well.

The new economy is often equated with the Internet economy, whose origins lie in the foundation of Natscape (Kogut, 2004:2) and its very successful IPO in 1995. To Godin (2004), the concept of the new economy arose from the growth project (OECD, 2000a) 
inspired by the strong economic performance of the United States in the 1990s. Although the popularity of the new economy faded somewhat after the crash of the Internet bubble in 2000, ICT has revolutionized most areas of economic and social life and today determines the path of economic growth (Kushida, and Zeeman, 2009). The attitudes about the role of R\&D in ICT are conflicting. Although it is commonly accepted that the ICT sector is highly intensive in research and development (García-Muñiz and Vicente, 2014) others hold that contribution of the ICT sectors to European countries in the period 2000-2005 was weakening and slowing economic growth due to the loss of export advantages and technical change related to the lower intensity of the R\&D activities and weaker linkage to the other emerging countries, especially in Asia" (Rohman, 2013, p.396). The new ICT based economy provides a ground of the knowledge economy but it cannot be equated with it.

The concept of the weightless economy is pioneered by Danny Quah (1999) whose understanding of dematerialized economy was quite different from the standard perception of knowledge economy driven by high-tech and scientific research. He challenges the idea that knowledge in economic life is always identical with knowledge in science and technology. The weightless economy is characterized by "knowledge-products, i.e., commodities whose physical properties resemble those of knowledge, regardless of whether the commodities themselves contain significant amounts of knowledge as traditionally understood“(Quah, 1999:2). The weightless economy draws strength from consumers who are not ivory-tower academics or managers but rather, for the most part, ordinary people who are "caught by globalization pushed hard against the chalkface of technical progress"(Quah, 1999a). The main value of commodity comes, it is argued, from its "weightless" attributes derived from its design, its brand, image, the way in which it is marketed or individualized to the customers' desire. Besides the Quah's influential works, the book by D. Coyle (1997) “The 
Weightless World" is referred to as the first book to map an economic world that has been turned upside down by digital technology and global business."

Preposition 6. Creativity and introduction of new business models are the most meaningful source required for growth. Cultural and creativity-based competition is highly attractive since it is abundant by jobs and does not require long-term technological accumulation, painstaking learning, large investments or mastery of advanced technical skills in the natural and technical sciences. Even the least developed country has a chance to compete by virtue of its brainpower or, to use a broader term, human creativity. However, its sustainability and consequences on growth remain unknown.

In contrast with the weightless economy, whose influence on economic theory and practice has been limited, the cultural economy (Hesmondhalgh, 2013) and creative economy (Florida, 2002; Howkins, 2001) have exploded, transitioning from representing a relatively insignificant portion of economic life to becoming major players in advanced economies since the 2000s, when culturalization of the economy become a key to success in crowded and competitive markets (Pratt and Jeffcutt, 2009).

These economies' strengths include 1) annual growth rates of between 5\% and $20 \%$ in cultural industries, as estimated in OECD countries and 2) their huge potential to create employment, exports and growth (European Commission, 2005a). The expected economic benefits of culturalization are rooted in the nature of cultural and creative activities, which are labor intensive, foster innovation and individual entrepreneurialism, and are widespread (as they do not depend on an individual's specific technical, scientific or expert abilities). Regardless of the semantic, historical and conceptual differences between these industries (Hesmondhalgh, 2008), the creative and cultural economies include a colorful bundle of artistic sectors such as the visual arts (e.g., painting and sculpture); performing arts (e.g., theatre and opera); heavily industrialized sectors such as advertising and marketing; software; broadcasting; film; the Internet; fashion; design; artistic crafts; and architecture, as well as research and scientific activities. The early effort of the European Commission to analyze the socio-economic impact of the cultural sector in Europe has resulted in a comprehensive study 
„The Economy of Culture in Europe” (European Commission, 2006) and since then has become a part of the regular monitoring within the Extension of the European Cluster Observatory. The latest report emphasizes the great significance of cultural and creative industries for economic growth in the EU and promotes rhetoric that "innovation is increasingly driven by non-technological factors such as creativity, design and new organizational processes or business models" (European Commission, 2013a:13).

The weightless, creative and cultural economic models suggest that individuals are able to earn livelihoods and even grow wealthy simply by using their spirit, creativity and new ideas to produce immaterial (as opposed to physical) products. In fact, the aforementioned economies do not acknowledge an essential economic difference between scientific/technological knowledge and the products of the human spirit; scientific breakthroughs and mathematical theorems are judged as equivalent to human creations such "trash" TV shows, blockbusters and rock concerts in terms of their impact on socio-economic development. To Quah (1999a:6), for example, „Lara Croft Tomb Raider is a weightless knowledge-product that we enjoy or we sell - its economic and physical properties make it a prototypical product in the new hi-tech knowledge-intensive economy".

It cannot be denied that the weightless, cultural and creative economies are rather appealing by virtue of their "non-elitist" character and independence from high technology, which excludes less economically and technologically, developed countries from current global economic trends. Opponents of the weightless economy point to a lack of evidence that creative economies are sustainable or can solve the problem of unemployment and falling production by promoting the creation of low-paid, low-skilled jobs (Oakley, 2004; Witt, 2013) and neglect of knowledge based services (Miles, 2005) in parallel. Moreover, encouraging the acquisition of trivial skills can bring about a number of negative consequences and unintended social and cultural phenomena, such changes in value systems, 
lifestyle, or work ethic or social exclusion (i.e., by broadening the gap between the low-skill jobs and techno-managerial elites).

The erosion of the knowledge economy has been accelerated by the appearance of the financialised economy, in which "profit making occurs increasingly through financial channels rather than through trade and commodity production" (Kripner, 2005:174). Although this phenomenon cannot be elaborated upon here, it should be noted that financialization further eroded the concept of the knowledge economy because many have attributed the intangibles inherent to the financial sector (e.g., securities, bonds, and premiums) and the negative features of financialization (such as public debts or the real estate bubble) to the knowledge economy as the dominant socio-economic paradigm in which we presently live.

\section{A Roadmap for Addressing the Knowledge Economy to Service Economy}

The evolution of the concept of research-driven innovation and change of the original notion of the knowledge economy culminated in the appearance of the service economy. Service economy is implicitly equated with knowledge economy because the investment in intangibles such as research and innovation is simply identified with the investment in services as just another form of intangible intellectual or mind production. Since technological progress have diminished the need for manufacturing and human labor many politicians strongly support services as a way to combat unemployment and the overall difficulties caused by globalization and de-industrialization. However, the global financial crisis helped to expose the hidden weaknesses and the deep-rooted conflicts inherent to the service economy. Growing social and economic inequalities, persistently rising unemployment, the weaker competitive position of most EU countries and a lack of perceived gains in wellbeing are some illustrative examples. It is estimated, for example, that 114 million people in the EU 
(i.e., $23 \%$ of the EU population) were at risk of poverty or social exclusion in 2009 (European Commission, 2011a).

A modest but growing number of analyses argue that it is necessary to pay more attention to deconstructing the myth of service economy (Jansson, 2009; Oakley, 2004; Ketokivi, 2009), including its structural deficiencies (Wölfl, 2005) and the fallacy (Solberg Søilen, 2012) arguing that the service economy is not sustainable in the long run.

Preposition 7. The processes of learning and research in service innovation are quite different from those found in industrial innovation, which is based primarily on the achievements and methods of the natural, technical, and biotechnical sciences and engineering.

Some argue that the service economy is nothing but a statistical illusion, a myth of high-tax welfare states (Jansson, 2009) generated by mistakenly dividing the economy into goods and services instead of according to the nature (i.e., material or immaterial) of the final output. The latter method reveals the dependence of services on production and reimagines the conventional share of services and goods in the economy (Jansson, 2009:186). A significant portion of the service sector is composed of the health, education and social care sectors (HEC), which are basically provided free of charge (the services under its umbrella are funded either by market-based services or manufacturing). The growth of low-value-added services threaten the HEC and welfare state, a fact that is already evident in less developed countries with small production bases. Above all, overestimation of services threatens the research and education sectors, which are mostly funded by constantly declining public resources, and therefore diminishes the basis of the knowledge economy.

Services are often perceived as characterized by low knowledge intensity (Wölfl, 2005) while, by contrast, modern manufacturing (not only in high-tech industries, but also low- and medium-tech ones) creates and deploys many forms of knowledge that are relevant for production, including basic science results (Hirsch-Kreinsen, et al, 2003). Service innovations reduce the need for $R \& D$ and education, particularly in technical and scientific 
fields, and thereby lessen the "epistemic base of technique" (Mokyr, 2003). R\&D and manufacturing are physically collocated and a tendency for unbundling them (for example, by relocating production to low-wage countries) is possible for some companies but for many others is simply a post-industrial myth (Ketokivi, 2009).

With the exception of knowledge-based, highly professional services such as those found in the financial or health care sectors, service innovations primarily require low-wage, low-skill, routinized work and thus lead to the deskilling or 'McDonaldization' of society (Gatta at all, 2005). Coupled with a number of unemployed in the EU that hits a new height of 26.9 million in September 2013 (European Commission 2013b:36) it leads to the precarious and a non-standard "flexible" employment that is poorly paid, insecure and unprotected (Standing, 2011). Coyle (1997) states that much of the growth in jobs will occur in sectors within the social economy, such as individual communities, social and personal services, charities, etc. which was confirmed by the share of $29 \%$ of GDP expenditures in the EU on social protection recorded in 2011 (Eurostat, 2013).

In Europe, according to Eurostat ${ }^{2}$ the proportion of low-wage earners has been either in the steady state or increased over the period 2006-2010 in many countries, especially the old western economies, such as the UK, Austria, Germany and Italy. The highest proportion of low-wage earners among the employed are in the services sectors, such as accommodation and chattering (44\%), administration (40\%), and wholesale $(25 \%)$, followed by the arts (23\%), real estate (13\%), industry $(13 \%)$ and, ICT (5\%).

In analyzing the U.S.'s competitiveness in the knowledge economy, Tassey (2004) draws several conclusions that are important for considering the role of research and education in the knowledge-based economy. First, knowledge-based services, which are usually perceived as a way to escape economic stagnation, are at risk due to decreases in

\footnotetext{
${ }^{2}$ Eurostat table code: earn_ses_pub1s
} 
production, as they typically represent the final stage in a system of products related to consumption (e.g., communication, marketing, or trade). Second, manufacturing is critical to an advanced economy's long-term growth and will continue to be so for the foreseeable future. Third, companies must conduct R\&D to create or absorb technologies from external resources. Additionally, industry has important spillover effects because it is based on constantly emerging new technologies and innovations and, therefore, encourages scientific research, technological accumulation and learning. Overreliance on services leads to a vicious circle in which a decline in industry reduces innovation, research capacities and educational needs, which in turn has a negative impact on industry.

$\mathrm{R} \& \mathrm{D}$ and education that are embedded in technological innovation and industrial production are still substantial contributors to the material reproduction of economies and societies, and they represent critical factors in the knowledge economy (Gambardella and McGahan, 2010).However, analyses of the EU's competitiveness with respect to overall research and innovation revealed that it has been progressively declining over the last decade, particularly in the private business sector, which is especially worrying (European Commission, 2011:15). It is important to stress that, without structural changes in the research and innovation sectors (Heger and Rohrbeck 2012), the EU economy and its future economic competitiveness with respect to high-value-added products and services may be at risk. That said, it is rather encouraging that, after the decades in which industry's share in the European GDP fell sharply, there are broad initiatives for rebuilding the industrial ecosystem (European Commission, 2012b).

Preposition 8. The knowledge intensive business services (KIBS) and high-and medium-high technology manufacturing sectors while of growing importance, remains smaller in the aggregate than other parts of the economy; it calls for reconsidering of scientific research and technological innovation for economic growth. 
According to EUROSTAT the share of knowledge intensive activities (KIAs) represents a respectful 35.6\% of total employment in EU 28 in 2012 while the share of knowledge intensive services (KIS) amounts to 39.2\% in 2013. However, more detailed insight reveals that KIA and KIS do not apply the standard criteria of research intensity used to define the high to low-tech industries based on $R \& D$ expenditures by sectors as defined by OECD (2011). By contrast, they involve a colorful bundle of jobs which ranges from more creative/cultural activities (e.g. broadcasting, motion picture, entrainment, tour operators) to more intellectual activities like information, legal and financial service, etc. Yet these activities are presumably quite common and does not require special expertise scientific research base.

On the other hand, knowledge intensive activities in business industry (KIABI) including knowledge intensive business services (KIBS) represent a modest 10-25\% of total employment in the large majority of EU countries in 2012, with $13.8 \%$ in the EU on average $^{3}$. Similarly the high and medium-high technology manufacturing sectors employ only $5.6 \%$ of total employment in EU 28 in 2013. These data illustrate the need not only for improvement of vague and somehow misleading definition of knowledge intensive sectors but also a need for reconsidering the role of scientific research and technological innovation in gaining a new momentum to economic growth and social development.

\section{Conclusion}

An investigation into the historic and conceptual roots of the knowledge economy reveals that the original concept of the knowledge economy in Europe has evolved since the 2000s due to the restructuring of global economy from manufacturing towards services supported by the paradigm shift in both the concept of "knowledge economy" in general and

\footnotetext{
${ }^{3}$ Eurostat table code: htec_kia_emp2
} 
"knowledge" in particular. These circumstances have questioned the European Union's ability to transform into a highly competitive knowledge-based economy, but the precise cause of the failure is debatable. Analysis has identified several factors that could explain this lag in Europe's international competitiveness. On a general socio-economic level, these reasons could include banking system dysfunction; severe fiscal austerity; high debt; reductions in key demographics; a decreased demand for goods; declining exports; real estate bubbles, etc. (European Commission, 2011). In the specific areas of research and innovation, the most common deficits included low investment in $R \& D$, weak innovation capacities, a lack of human capital, a low rate of entrepreneurship, a low rate of ICT adoption (European Commission, 2011 and 2012a, Johansson et al, 2007). By contrast, the Knowledge for Growth Expert Group (K4G, 2007) concluded that "the $R \& D$ deficits appear to be a symptom, rather than the cause of weaknesses in the EU's capacities to innovation". According to this view, deficits in R\&D - and, specifically, the shortage of new technology-based entrants in the EU—reflect the characteristics and dynamics of an enterprise structure.

Change in the understanding of the concept of knowledge from scientific knowledge to services and creativity has been generated through a plethora of new conceptualization of economy such as new/Internet, weightless, cultural, creative or financialised economy which are nowadays commonly understood as a part of service economy. Knowledge economy is implicitly equated through this evolution with service economy because the investment in intangibles such as research and innovation is somewhat uncritically identified with the investment in services as just another form of intangibles driven by human intellectual/mind production as opposed to industrial production. The exchange of "service intangibles" for "knowledge intangibles" transform the original concept of the knowledge economy which was rooted in capitalizing on science as a complex non-linear process of technological innovation towards the service economy rooted in capitalizing the knowledge intensive 
activities (KIAs) where knowledge is perceived to be generated not as a product of scientific research but as a service or creative activity. However, KIAs are still rather vague concept in which the role of scientific research and research based innovation is quite weak, unclear and elusive at least perceived through a low proportion of KIABI, KIBS and high- to mediumhigh technologies in economy. Therefore, an uncritical overreliance on services without clear position of scientific research and technological innovation might further weaken the competitive position of the European countries vis-à-vis new emerging economies. It might also create a vicious circle in which a decline in industry generate decline in R\&D and educational needs, which in turn worsens industry's decline. This threatens the very foundations of the knowledge economy and requires, thus, reconsideration of the role of scientific research and technological innovation in both service and industrial sectors to gain a new momentum to economic growth and social property.

It seems that the new endeavors are needed to encourage European economies to transform from low perspective service activities into the knowledge-intensive service economy (KISE) with higher proportion of high tech production and high-tech service sectors. Such activities could reconcile scientific research, technological innovation and service activities needed for dormant knowledge economy to revive. 


\section{References}

1. Abramovitz, M. (1989).Thinking About Growth, New York: Cambridge University Press.

2. Adam, F. (2014). Measuring National Innovation Performance, The Innovation Union Scoreboard Revisited, Heidelberg. New York, Dordrecht, London: Springer.

3. Antonelli, V. and Fassio, C. (2014), The economics of the light economy: Globalization, skill biased technological change and slow growth, Technological Forecasting \& Social Change, 87, 89-107.

4. Archibugi, D., Coco, A. (2005).Is Europe Becoming the Most Dynamic Knowledge Economy in the World? Journal of Common Market Studies. 43 (3) 433-459.

5. Audretsch, D.B. (2009). The entrepreneurial society. Journal of Technology Transfer, Vol. 34, 245-254.

6. Bell, D. (1973). The Coming of Post Industrial Society. New York: Basic Books.

7. Bell, M., Pavitt, K. (1993).Technological accumulation and Industrial growth: Contrasts between Developed and developing Countries. Industrial and corporate change, 2(2), 157-210.

8. Block, J.H., Thurik, R., Zhou, H. (2013). What turns knowledge into innovative products? The role of entrepreneurship and knowledge spillovers. Journal of Evolutionary Economics, Vol. 23, 693-718.

9. Carayannis, E.G., Grigoroudis, E., Sindakis, S., and Walter, C. (2014), Business Model Innovation as Antecedent of Sustainable Enterprise Excellence and Resilience. Journal of Knowledge Economy, Vol. 5, No. 3, pp. 440-463.

10. Carlaw, K., Oxley, L., Walker, P. Thorns, D., Nuth, M. (2006). Beyond the hype: Intellectual property and the knowledge society/knowledge economy. Journal of economics surveys, 20 (4), 633-690.

11. Coyle, D. (1997). The Weightless World: Strategies for Managing the Digital Economy. Capstone Publishing Limited.

12. Dasgupta, P. and David, P. (1988). Priority, Secrecy, Patents and the SocioEconomics of Science and Technology. Stanford University, Research Paper. No. 127.

13. Dubina, I.N., Carayannis, E.L. and Campbell., D. F.( 2012), Creativity economy and a crisis of the economy? Coevolution of knowledge, innovation and creativity, and of the knowledge economy and knowledge society, Journal of Knowledge economy, Vol. 3, No.1, 1-24.

14. Drucker, P. (1969.) The Age of Discontinuity: Guidelines to Our Changing Society, New York: Harper \& Row.

15. European Council (2000). Presidency Conclusions, 100/1/00. Lisbon. 23-24 March 2000.

16. European Commission (2005). Working together for growth and jobs: A new start for the Lisbon Strategy. COM(2005) 24 Final, February 2.

17. European Commission (2006), The Economy of Culture in Europe, Study prepared for the EC, http://ec.europa.eu/culture/library/studies/cultural-economy_en.pdf. Accessed 13 February, 2015)

18. European Commission (2005a). The future of Creative Industries: implications for research policy. Fore sighting Europe, Issue 7, 1st quarter 2005, p. 7 
19. European Commission (2010).Europe 2020 - A Strategy for Smart, Sustainable and Inclusive Growth. COM (2010).

20. European Commission (2010a). Lisbon Strategy evaluation document. Commission Staff Working Document Brussels, 2.2.2010, SEC(2010) 114 final.

21. European Commission (2011). Innovation Union Competitiveness Report, EUR 24211, Brussels.

22. European Commission (2011a). Employment and Social Developments in Europe 2011. European Commission, Directorate-General for Employment, Social Affairs and Inclusion.

23. European Commission (2012). Action for Stability, Growth And Jobs. COM(2012) 299 Final, May,30.

24. European Commission (2012a). State of the Innovation Union 2012 - Accelerating Change. COM (2013) 149 final, March, 21.

25. European Commission (2012b). A Stronger European Industry for Growth and Economic Recovery. COM (2012) 582 final, October, 10.

26. European Commission (2013). European Economic Forecast. European Economy $7 \mid 2013$.

http://ec.europa.eu/economy_finance/publications/european_economy/2013/pdf/ee7_e

n.pdf. Accessed 8 September, 2014

27. .

28. European Commission (2013b). Employment and Social Developments in Europe 2013. Brussels.

29. Eurostat (2013). Social protection. Eurostat News release, 174/2013, 21 November 2013.

30. Florida, R. (2002). The Rise of the Creative Class. New York: Basic Books.

31. Freeman, C. (1988). Japan: a new national system of innovation? In Dosi, G., et al. (eds), Technical Change and Economic Theory (London: Pinter Publishers) pp. 330348.

32. Freeman, C., Soete. L. (2007). Developing science, technology and innovation indicators: what we can learn from the past". UNU-MERIT, Working paper series.

33. Gallouj, F., Matthias Weber, K., Stare, M., Rubalcaba, L. (2015), The futures of the service economy in Europe: A foresight analysis, Technological Forecasting \& Social Change, article in press

34. Gambardella, A., and McGahan, A.M. (2010), Business model innovation: General purpose technologies and their implication for industry structure. Long Range Planning, Vol. 43, pp. 262-271.

35. García-Muñiz, A.S., Vicente, M. R. (2014). ICT technologies in Europe: A study of technological diffusion and economic growth under network theory". Telecommunication Policy, 38,(4) 360-370.

36. Gatta, M., Boushey, H., Appelbaum, E. (2005). High-Touch and Here-to-Stay: Future Skills Demands in US Low Wage Service Occupations. Sociology, 43 (5) 968989.

37. Godin, B. (2004). The New Economy: What the Concept Owes to the OECD. Research Policy, 33 (5) 679-690. 
38. Godin, B. (2008). Innovation: The History of a Category, Working Paper No. 1.

39. Godin, B. (2011). The rise of innovation surveys: measuring a fuzzy concept. "http://www.sussex.ac.uk/Units/spru/events/KP_Conf_03/documents/Godin.pdf. Accessed 8 September, 2014.

40. Heger, T., and Rohrbeck, R. (2012) Strategic foresight for collaborative exploration of new business fields. Technological Forecasting and Social Change, Vol. 79, No. 5, pp. 819-831.

41. Hesmondhalgh, D. (2013) The Cultural Industries, $3^{\text {rd }}$ edition. London, Los Angeles and New Delhi: SAGE.

42. Hesmondhalgh, D. (2008). Cultural and Creative Industries, In Bennett, T. and Frow, J.(eds.) The Sage Handbook of Cultural Analysis, 552-569. Sage Publications Ltd.

43. Hitt, M.A., Ireland, R.D. and Lee, H. (2000) 'Technological learning, knowledge management, firm growth and performance', Journal of Engineering and Technology Management, Vol. 17, pp.231-246.

44. Hirsch-Kreinsen, H. Jacobson, D., Laestadius, S. and Smith, K. (2003). Low-Tech Industries and the Knowledge Economy: State of the Art and Research Challenges. STEP REPORT 16-2003. http://www.nifu.no/files/2012/11/STEPrapport200316.pdf'. Accessed 8 September, 2014.

45. Howkins, J. (2001). The Creative Economy: How People Make Money from Ideas, London: Penguin Books.

46. Hughes, S.M. (2011). Genentech: The beginnings of biotech, The University of Chicago Press.

47. Jansson, J.O. (2009). The myth of the service economy - an update, Futures, 41(3) 182-9.

48. Johansson,B., Karlsson, C., Backman, M., Juusola, P. (2007). The Lisbon Agenda from 2000 to 2010. CESIS Electronic Working Paper Series, Paper No.106. http://www.diva-portal.org/smash/get/diva2:487429/FULLTEXT01.pdf. Accessed 13 February, 2015

49. Ketokivi, M. (2009). Unbundling R\&D and Manufacturing: Postindustrial Myth or Economic Reality? Review of Policy Research, Vol. 26, No. 1-2, pp.35-54.

50. Kline, S.J. and Rosenberg, N. (1986). An Overview of Innovation, in Landau, R. and Rosenberg, N. (eds.) The Positive Sum Strategy: Harnessing Technology for Economic Growth, Washington D.C.: National Academy Press, 275-304.

51. Kogut, B. (ed.) (2004). Introduction: The Internet Has borders, In: Bruce Kogut (ed.) The global internet economy, The MIT Press.

52. Kok, W. (ed). (2004). Facing the Challenge. The Lisbon Strategy for Growth and Employment, Brussels: European Commission.

53. Krippner. G. R. (2005). The financialization of the American economy". SocioEconomic Review, 3 (2) 173-208.

54. Kirzner, Israel.(1973) Competition and Entrepreneurship. Chicago: University of Chicago Press

55. Kushida,,K. E., Zysman, J. (2009). The Services Transformation and Network Policy: The New Logic of Value Creation. Review of Policy Research, 26 (1-2), 173-194. 
56. K4G (2007). What policies are needed to overcome the EU's R\&D deficit. Knowledge for Growth Policy Debate No. 1, October 2007. http://ec.europa.eu/invest-inresearch/pdf/download_en/policy_debate.pdf. Accessed 8 September, 2014.

57. Lall, S. (1995). Science and technology in the new global environment: implications for developing countries. UNCTAD, Science and Technology Issues

58. Lundvall, B.-A. (ed), (1992). National Systems of Innovation. Towards a Theory of Innovation and Interactive Learning, London: Pinter.

59. Machlup, F. (1962). The Production and Distribution of Knowledge in the United States, Princeton: Princeton University Press.

60. Maglio, P. P., Kieliszewski, C. A. and Spohrer, J. C. (eds) (2010). Handbook of Service Science, New York: Springer.

61. Mendonça, S. (2009). Brave Old World: Accounting for 'High-Tech' Knowledge in 'Low-Tech' Industries. Research Policy, 38 (3) 470-482.

62. Miles, I. (2005), Knowledge intensive business services: prospects and policies, foresight, Vol. 7., No. 6 pp. $39-63$, DOI:http://dx.doi.org/10.1108/14636680510630939

63. Mokyr, J. (2003). The Knowledge Society: Theoretical and Historical Underpinnings, Presented to the Ad Hoc Expert Group on Knowledge Systems, United Nations, New York, Sept. 4-5, 2003.

64. Nelson, R. R. (1959). The simple economics of basic scientific research, Journal of Political Economy, 67 (3) 297-306.

65. Nelson, R. and Winter, S. (1982). An Evolutionary Theory of Economic Change, Cambridge: Harvard University Press.

66. Nauwelaers, C. and R. Wintjes (2002), Improving Trans-national Policy Learning in Innovation, report for the European Commission (DG Enterprise), November, Innovation Trend Chart project, Luxembourg

67. Oakley, K. (2004). Not So Cool Britannia: The Role of the Creative Industries in Economic Development. International Journal of Cultural Studies, 7 (1) 67-77.

68. OECD (1996). The Knowledge Based Economy, Paris: OECD.

69. OECD (2000). The service economy, Paris: OECD)

70. OECD (2000a). A New Economy? The Changing Role of Innovation and Information Technology in Growth", Paris: OECD.

71. OECD (2002). Frascati Manual. Proposed standard practice for surveys on research and experiment development, Paris: OECD.

72. OECD (2005). Oslo Manual: Guidelines for Collecting and Interpreting Innovation Data, Third Edition, Paris: OECD.

73. OECD (2011), ISIC rev. 3 technology intensity definition, OECD Directorate for Science, Technology and Industry, 7 July, 2011, available at: http://www.oecd.org/sti/ind/48350231.pdf, (accessed 15 December, 2014).

74. OECD (2012). Science, Technology and Innovation Outlook in 2012, Paris: OECD.

75. Pratt, A.C. and Jeffcutt, P. (2009). Creativity, innovation and the cultural economy: Snake oil for the twenty-first century? In Pratt, C. and Jeffcutt, P. (eds) Creativity, Innovation and the Cultural Economy London and New York: Routledge, Taylor and Francis Group, 1-19. 
76. Quah, D. (1999). The Weightless Economy in Growth. The Business Economist. 30 (1), 40-53. http://econ.lse.ac.uk/ dquah/". Accessed 8 September, 2014

77. Quah, D. (1999a). Unpacking globalisation and new technology in Britain. Economics Department LSE, http://econ.lse.ac.uk/ dquah/p/9911esrc.pdf. Accessed 8 September, 2014

78. Rohman, I.K. (2013). The globalization and stagnation of the ICT sectors in European countries: An input-output analysis. Telecommunication Policy, 37 (4-5) 387-399.

79. Romer, M. P. (1989). Endogenous technical change. National Bureau of Economic Research, Working paper serious, No. 3210.

80. Rosenberg, N. (1985). The commercial exploitation of Science by American industry" In Clark, K. B. at al (eds) The Uneasy Alliance, Boston and Massachusetts: Harvard Business School Press, pp. 19-50.

81. Rosenberg, N. and Nelson, R. R. (1994). American university and technical advance in industry. Research Policy, Vol. 23, pp. 323-348.

82. Schumpeter, J.A. (1934). Theory of Economic Development, Cambridge: Harvard University Press.

83. Solberg Søilen, K. (2012).The fallacy of the service economy: a materialist perspective. European Business Review, 24 (4), 308-319.

84. Solow, M. R. (1957). Technical change and the aggregate production function. Review of Economics and Statistics, 39.

85. Standing, G. (2011) The Precariat: The new dangerous class. London: Bloomsbury Academic.

86. Tassey, G. (2004). Policy Issues for R\&D Investment in a Knowledge-Based Economy. Journal of Technology Transfer, Vol. 29, 53-185

87. Turro, A.; Urbano, D.; and Peris-Ortiz, M. (2014). Culture and innovation :the moderating effect of cultural values on corporate entrepreneurship, Technological Forecasting and Social Change, Vo. 88, pp. 360-369

88. Uppenberg, K. and Strauss, H. (2010). Innovation and productivity growth in the EU services sector; European Investment Bank, July 2010.

89. Witt, U. (2013), Environmental Innovation and Societal Transitions: Viewpoint, Environmental Innovation and Societal Transitions , 6, 120-122

90. Wölfl, A. (2005). The Service Economy in OECD Countries, OECD Science, Technology and Industry Working Papers, 2005/03, OECD, Paris. 